\title{
THE COMPETENCE FOR PROJECT TEAM MEMBERS IN THE CONDITIONS
} OF REMOTE WORKING

\author{
Iwona ZDONEK*, Marzena PODGÓRSKA**, Beata HYSA*** \\ Silesian University of Technology in Gliwice, Faculty of Organization and Management, Poland \\ *e-mail: iwona.zdonek@polsl.pl \\ ** e-mail: marzena.podgorska@polsl.pl \\ *** e-mail: beata.hysa@polsl.pl
}

\begin{abstract}
The article presents results of the qualitative research on competence of project team members in the conditions of remote working. These competences were considered in relation to different roles, which the members of such a team accept. The reference point to studied roles was the concept of Hansen and Allen authorships, and with regard to competence, the author's synthesis of deliberations above their models described in the literature.
\end{abstract}

Keywords: project management, remote working, competence of project team members, roles in the project team.

\section{$1 \quad$ Introduction}

Organizations in today's dynamically developing economy are more often forced to seek specialists in different areas outside their company's offices. Therefore, it may happen that implementation of the given project is a cooperation of different experts from different fields and with different experiences.

Thanks to modern information and communication technologies (ICT), such cooperation becomes possible. In this way, there are appointed teams working on the project in remote conditions. No wonder that conditions of such cooperation have become the subject of scientists' research (Twardochleb, 2015; Morley, Cormican, Folate, 2015; Hamersly, Land, 2015; Piccoli, Powell, Ives, 2004).

An issue of competence of the team members with regard to their role in the project attracted the attention of article's authors. Hence, the aim of this article is to determine the main competence of individual project team members in conditions of remote working. The issue of recalled competence was studied in relation to the role, which team members perform in the project.

Different competence concepts, such as L.H. Crawford (2007), A. Rakowska (2007), R.L. Katz (1995), J.C. Carter (2009), I. Zdonek and M. Wolny (2015), as well as HOTS concept of roles division in the project team proposed by M.V Hansen and R.G Allen, were used as the theoretical background to the study.
The basic research methods used were participatory observation and interviews with persons involved in such works.

The article was organized in the following way. First chapter presents the most important definitions and theories associated with the competence concepts, and the role in the team. Different points of view presented by the most important researchers were analyzed in these deliberations. Second chapter describes the methodological aspects of conducted studies, and the third chapter presents research results. Discussions of received results and main conclusions were described in the fourth chapter.

\section{Competence and roles of the project team - essence of this issue}

The basic elements of every project or task force are the people who carry out the project. They decide whether the project will be a success or a failure. Therefore, the selection of employees to the project team at the stage of determination of project resources is very important. They are the driving force of the entire project (Kiełtyka, 2016). Success or failure is determined by the quality and involvement of staff members (Wróblewski, 2005).

In order to achieve success, the project team must have certain skills and competencies to carry out the entrusted task, and thus, affecting the success of each project. 


\subsection{Competence in the project team - definitions and models}

It is hard to define the concept of competence; it is even possible to state that in our times, there is no clear definition of the competence. A. Wasiluk (2008), as well as B. Hysa and A. Rakowska (2014) noted that most authors, who study the subject matter of competence, create their own definitions or inter- pret it differently, depending on the accepted research context. Moreover, many researchers (Bratnicki, 2000; Chełpa, 2010; Listwan, 2010; Thierry, Sauret, 1994) use terms close in meaning to competence, such as qualifications, skills or abilities. A comparison of selected competence definitions is presented in Table 1 .

Table 1. Definitions of competence

(source: own elaboration with: A Guide to the Project Management Body of Knowledge 2013; Crawford, 2007; Jokinen, 2005; Musioł-Urbańczyk, 2010; Rakowska, Sitko-Lutek, 2000)

\begin{tabular}{|c|c|}
\hline Author & Definition \\
\hline G.O Klemp (1980) & $\begin{array}{l}\text { Set of characteristics of the given person that enables its effective } \\
\text { and (or) standing out fulfilment of tasks associated with performed } \\
\text { work. }\end{array}$ \\
\hline R. Boyatzis (1982) & $\begin{array}{l}\text { Set of characteristics of the given person, which consist of: } \\
\text { motivation, personal features, abilities, self-assessment associated } \\
\text { with functioning in the group and knowledge, which this person has } \\
\text { acquired and which he uses. }\end{array}$ \\
\hline S.B. Parry (1998) & $\begin{array}{l}\text { Knowledge, abilities and attitudes related to effective action } \\
\text { of the manager. }\end{array}$ \\
\hline A. Rakowska, A. Sitko-Lutek (2000) & General knowledge, skills and rights. \\
\hline A. Sajakiewicz (2002) & $\begin{array}{l}\text { Set of knowledge, skills, styles of action, personality, principles, } \\
\text { interests and other features, which are used and developed } \\
\text { in the process of work and lead to achievement of results that are } \\
\text { compatible with the strategic business objectives. }\end{array}$ \\
\hline G. Filipowicz (2004) & $\begin{array}{l}\text { Orders in terms of knowledge and skills that are effective in } \\
\text { performed role of the manager. }\end{array}$ \\
\hline T. Jokinen (2005) & $\begin{array}{l}\text { (...) certain personal features, behaviors, abilities, values, } \\
\text { knowledge and many existing structures, which are their } \\
\text { combination. }\end{array}$ \\
\hline L.H. Crawford (2007) & $\begin{array}{l}\text { Knowledge, abilities and personal features required to achieve } \\
\text { the effectiveness of work determined in standards. }\end{array}$ \\
\hline PMI (2013) & $\begin{array}{l}\text { Required skills and abilities to complete the project activities } \\
\text { in accordance with accepted design limitations. }\end{array}$ \\
\hline
\end{tabular}

Analyzing the definitions presented in the literature (Table 1), it is possible to notice that they refer both to narrow and wide presentations of competence. Narrow scope of competence (among others G. Filipowicz or O.G. Klemp's definitions) refers to skills or knowledge, and wide perspective (among others R. Boyatzis, L.H. Crawford, T. Jokinen, A. Sajakiewicz or S.B. Parry's definitions), and additionally includes personality features, attitudes, experience, values or behaviors. 
With regard to wide recognition of competence, it is worthwhile to draw attention to the concept of L.H. Crawford (2007). The author, based on reviewed literature, has developed the model of competence, in which she considered three groups of competence: input competence (knowledge, qualifications, experience, abilities), personal competence (features, behaviors, attitudes, emotions) and output competence (visible results, standards), which creates a cohesive set comprising the so-called "total competence".

The model also includes situational requirements (internal context, nature of situation, nature of performed role and other team members), which can affect results of the given undertaking (Turner, Müller; 2010). With regard to the model mentioned above, it is possible to show that competences are recognized very widely in it, as personal features, knowledge, abilities, experience and qualifications, which should correspond to existing conditions in order to generate correct results.

R.L. Katz (1995) model of competence is also often referred to in the literature. The author distinguishes in it: conceptual competence (creative sense of direction), social competence (interpersonal), and technical competence (professional, specialist).

Competence limits are flexible, they change depending on the size of teams directly or indirectly supervised and on the situations. On the high levels of management, abilities concerning interaction with surroundings, interpersonal relations, organizational efficiency, abilities of wide conceptual and strategic thinking gain importance.

A. Rakowska model of competence is another important model, where competence includes abilities, knowledge, attitudes and personality features, which are characteristic for persons achieving high results (Rakowska, 2007). In this model, the competence concerns ability to transfer the skills and knowledge in new situations within the profession. This means that competence should also be associated with actions if possible to determine results.

Therefore, it should be noted that in addition to typical characteristics that describe the competence, there are a number of personality features not easily visible and identified, and which can have a significant effect on the success of tasks performed by the person. Hofricher and Spencer (1996) determine these features in free translation as "hidden agenda", characteristics of the employee or "soft" competence. For example, such features as system of values, employee's personality, attitude, may affect the success of carried out tasks and decision making in similar degree as, for example, technical competence.

These special "soft" features of the employee can also be described as the potential. J.C. Carter (2009) defines the concept of "high potential" as a combination of ability and commitment, with aspiration to development, promotion and to perform key roles in the organization. I. Zdonek, M. Wolny (2015), by defining the variables shaping the potential of an employee, pointed to additional important psychological and social variables such as desire for recognition and distinctions, passion of learning and development, determination in achieving objectives, involvement in work and organization and others.

Therefore, it is possible to assume that the potential dictates that some employees, despite lacking sufficient classification and knowledge, can cope with new challenges as compared to their fully qualified colleagues.

It is worthwhile to point that in the literature, often the competence of the project manager is discussed (Musioł-Urbańczyk, 2010; Wachowiak, et al., 2004; Polish Guidelines of Competence IPMA, 2009); however, the abilities of individual project team members are rarely identified. After all, it is important that persons who will cooperate with each other are not casual.

Taking the specificity of the given project into account, it is necessary to choose such employees, who are able to work in the group, aren't conflictual and have developed interpersonal skills. It is also important that team members should present a variety of competences, which will be mutually complementary. In addition, the team must consist of persons characterized by appropriate personality features, predispositions, with certain types of behavior, thanks to which a coherent cooperation of all members and efficient implementation of the given task is possible. 
It is best when the employees represent different roles in the team. It is necessary, when the task force is supposed to achieve synergy effect and successfully complete the task entrusted to them. Referring to the issue of the role in a team and considering the subject matter of this article, it is worthwhile also to note that the project team differs from the "traditional" one.

The project team in contrast to the traditional team has an impermanent and temporary structure. It is characterized by a smooth division of work, transitivity of entitlements, as well as low degree of formalization and standardization of action. Moreover, it should be noted that here a work of the team in remote environment is considered, where additionally it is necessary to take into account the spatial dispersion of team members, replacing the direct transmission of information with electronic communications, different working hours, multiculturalism, or independence from organizational structures.

Aspects mentioned above cause that even higher requirements are put for such team members, than in case of traditional teams. Therefore, what roles in the team should individual project team members perform?

\subsection{Roles in the project team}

Different concepts of team roles are presented in the literature. One of the most commonly referred is a concept of team roles of the authorship of R.M. Belbin (2009). The author treats the team role as a characteristic pattern of behavior of the team member, which appoints the direction of interaction with others, contributing to the development of the team as a whole.

He distinguishes eight team roles:

- practical organizer (Company Worker) - a man of action, practitioner, pragmatist,

- natural leader (Chairman) - dominating person with resources,

- man of action - (Shaper), that is the person orientated to tasks and rivalry, leader,

- sower (Plant), that is a person characterized by an originality, ingenuity and creativity,
- man of contacts (Resource Investigator), that is a person who obtains information and has good communication skills,

- judge - (Monitor-Evaluator), that is a logical observer and reviewer, objective man, pragmatist,

- man of group (Team Worker), that is a person who cares of good atmosphere in the team, social, who is able to resolve conflicts in the team,

- perfectionist (Completer-Finisher), that is a person who works hard on the details, "tides everything up".

Each of these roles is associated with certain personality types (Witkowski, Ilski, 2000). It is worthwhile also to add that each of the team members may take more than one role in the team, those with the abilities of flexible action can change it by adapting to the situation (Belbin, 2009).

Another often published in the literature concept in this area is HOST model (Hares, Owls, Squirrels, Turtles) of the authorships of (Hansen, Allen, 2002). The authors distinguish four roles: hare, owl, squirrel and turtle, which represent a wide variety of features and complement each other:

- Hares are persons characterized by creativity and tendency to take the risk. They generate ideas in the team; however, they also quickly lose interest in adopted idea and tend to drop out along the way.

- Owls are managers of projects. They take actions to fulfil the given idea. They define the priority of tasks and have good management skills.

- Turtles on the other hand, are critics, persons "managing" the risk and identifying all events, which can go wrong. They try to convince the team that earlier they never acted in a determined/planned way and this involves failure.

- Finally, the squirrel; without them nothing can be carried out and they perform most of the work in the project. They are focused on tasks, scrupulous, reliable, working in a thoughtful way and careful. $^{1}$

\footnotetext{
${ }^{1}$ Hots Team Structure in your Business:

http://www.oneminutemillionaire.org/hots-teams.html
} 
The four indicated roles guarantee effective cooperation of the team and are appropriate for teams with various complexity and form. M.V Hansen and R.G. Allen (2010) in their further research created one more theory of team roles, which assumes 4 roles in the team: leader, secretary, searcher missing in the action and planner. The leader represents the team outside, organizes meetings and directions of action. The secretary draws notes from meetings and sends them out to other members via e-mail. The planner sets dates of weekly meetings and reminds them to all team members.

Another important theory in the context of addressed issue is the theory of personality types MBTI by K.C. Briggs and I. Briggs Myers (Briggs-Myers, 1992). According to this theory, everyone has certain preferences (i.e., the way most often taken by the individual due to their easiness and naturalness), which can be presented on four opposing scales:

- As a part of the first E-I scale, people tend to focus on either the external factors (people and activity) or internal factors (thought and reflection).

- The second S-N scale determines the preferred way of collecting information. In this case, at one end of the scale people register specific, real and current facts, and at the other end have abilities to notice the general background of situation, as well as connections and relations between facts, which can be a source of inspiration for other activities.
- The third T-F scale refers to the process of decision making. On the one hand, it presents people who take into account knowledge, logic, specific rules and intellect in decision making, and on the other hand, people who are guided by subjective values, empathy and personal approach to the given problem.

- The last, fourth J-P scale describes preferred style of action.

On one side of the scale are persons acting in a planned, systematic and order way, whereas on the other side are more flexible persons, open to new experiences and spontaneous activity. It should be noted that in accordance with assumptions of discussed concept, there are no good or bad preferences of action. Each of them is characterized by unique advantages, but at the same time has the risk potential. The characteristic behavior pattern of the given person results from dynamic interaction between all four preferred styles (Stankiewicz, Birr, 2014; Rashid, Duy, 2015).

\section{$3 \quad$ Methodology}

Considering the various models of competence presented in the literature, in the article, it was assumed that competency model consists of certain skills resulting from knowledge, and also the potential of the employee (Fig. 1).

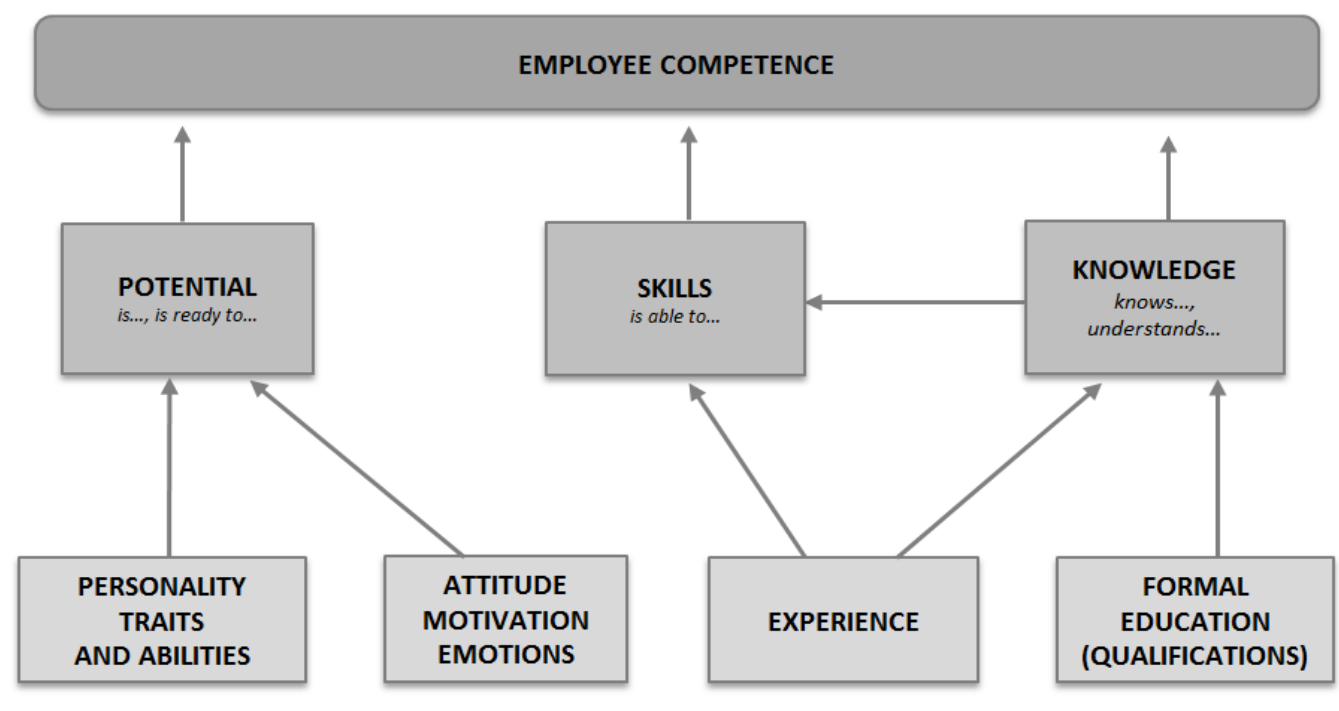

Figure 1. Model of competence

(source: own elaboration based on: Crawford, 2007; Rakowska, 2007; Carter, 2009; Zdonek, Wolny, 2015) 
Knowledge is formal education, qualifications and practical experience. The potential of an employee is not only his personality features, abilities, emotions, talents, but also the attitude of the employee's behavior and readiness to take new tasks and duties.

HOTS theory was selected for the study from proposed theories relating to roles in the team. The basic premise of this choice was the fact that authors of this article, as a part of participation in the work of different project teams, often worked in teams with such a structure, that is, in which it occurred and were easy to identify these four roles (hare, owl, squirrel and turtle).

In addition, the above-mentioned theory in comparison to other theories presented in the article is characterized by simplicity and possibility of simple practical implementation. What's more, the authors of HOST theory - M.V. Hansen and R.G. Allen (2002) through 4 roles, presented a consistent and holistic perspective of team roles, which additionally confirmed its selection to further analyses.

The basic research methods of this article were: participatory observation and interviews with persons working in the project team. Authors of the article in 2015-2016 were project team members working in remote conditions. They took different roles in those teams and both were initiators of the project and performed works from a range of manufacturing processes and management of the project.

Participatory observation created a very good access to study the competence of project team in conditions of remote working, thanks to the possibility of interaction and immersing in its circumstances (Verschuren, 2003; Czakon). Interviews were conducted in November 2016. They were half-structural and included open directional questions. Results of interviews and participatory observations are presented in the form of thought maps. These maps were proposed for each of the roles according to HOTS concept and based on the model of competence in Fig. 1.

\section{$4 \quad$ Result and finding}

The hare is a person initiating the project. This initiation is possible thanks to extraordinary creativity and leadership skills. In addition, this person easily establishes contacts, and therefore collects the project team for implementation and represents the team outside.

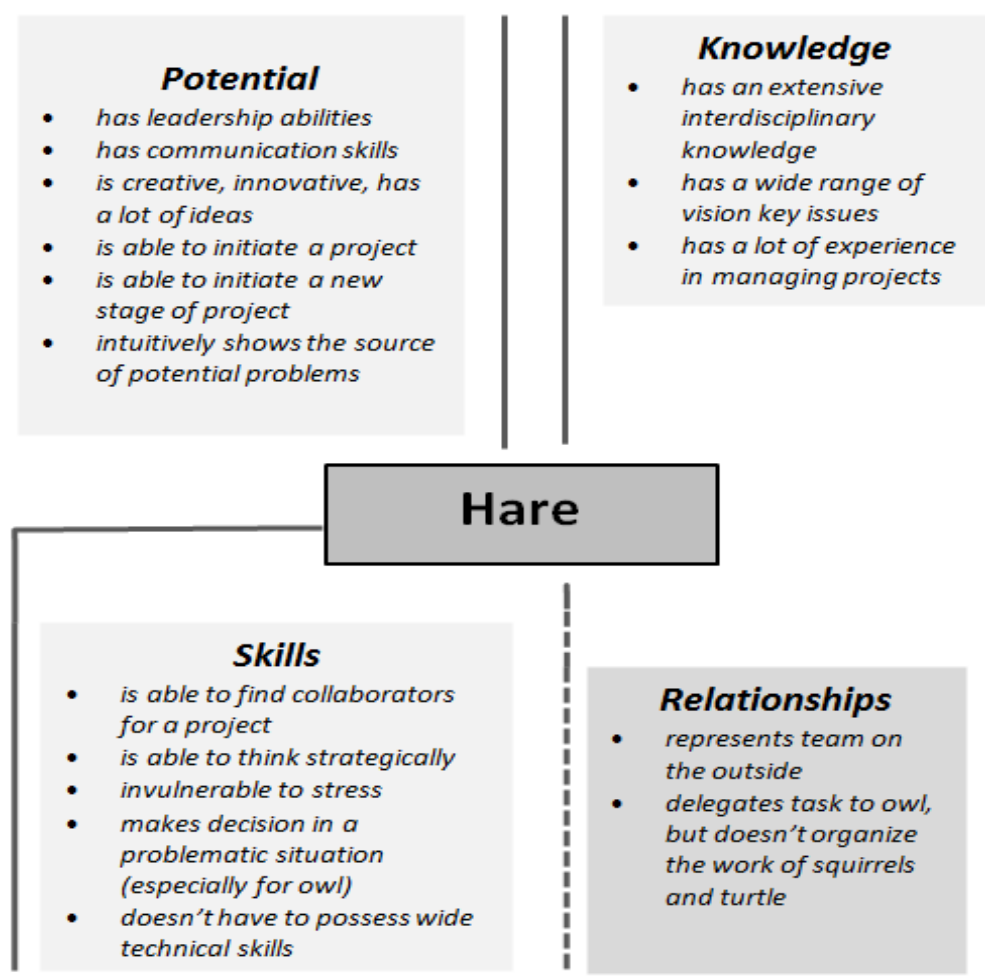

Figure 2. Competence of the hare (source: own elaboration) 
He usually has a lot of experience in running projects and also has extensive interdisciplinary knowledge, which results in huge creativity and wide perspective on the case of project.

Therefore, he intuitively indicates sources of potential problems and is able to make a decision in the problem situation. Hare usually works mainly with the owl, commissioning to it tasks on the global level of the project and entrusting the entire organization of works of the project team. In the aspect of team working in remote conditions, the hare does not need to have a wide digital competence.
General knowledge will be enough in this field for it. Hare usually has files available on the platform intended for remote cooperation, but doesn't manage them. This person assesses only the progress of project and supervises it in a global way. Competences of the hare were presented in Fig. 2.

An owl is a project manager, so-called right-hand man of the hare. The entire organization of squirrels' and turtles' work lies under its responsibility. It must be a person with very good organizational abilities.

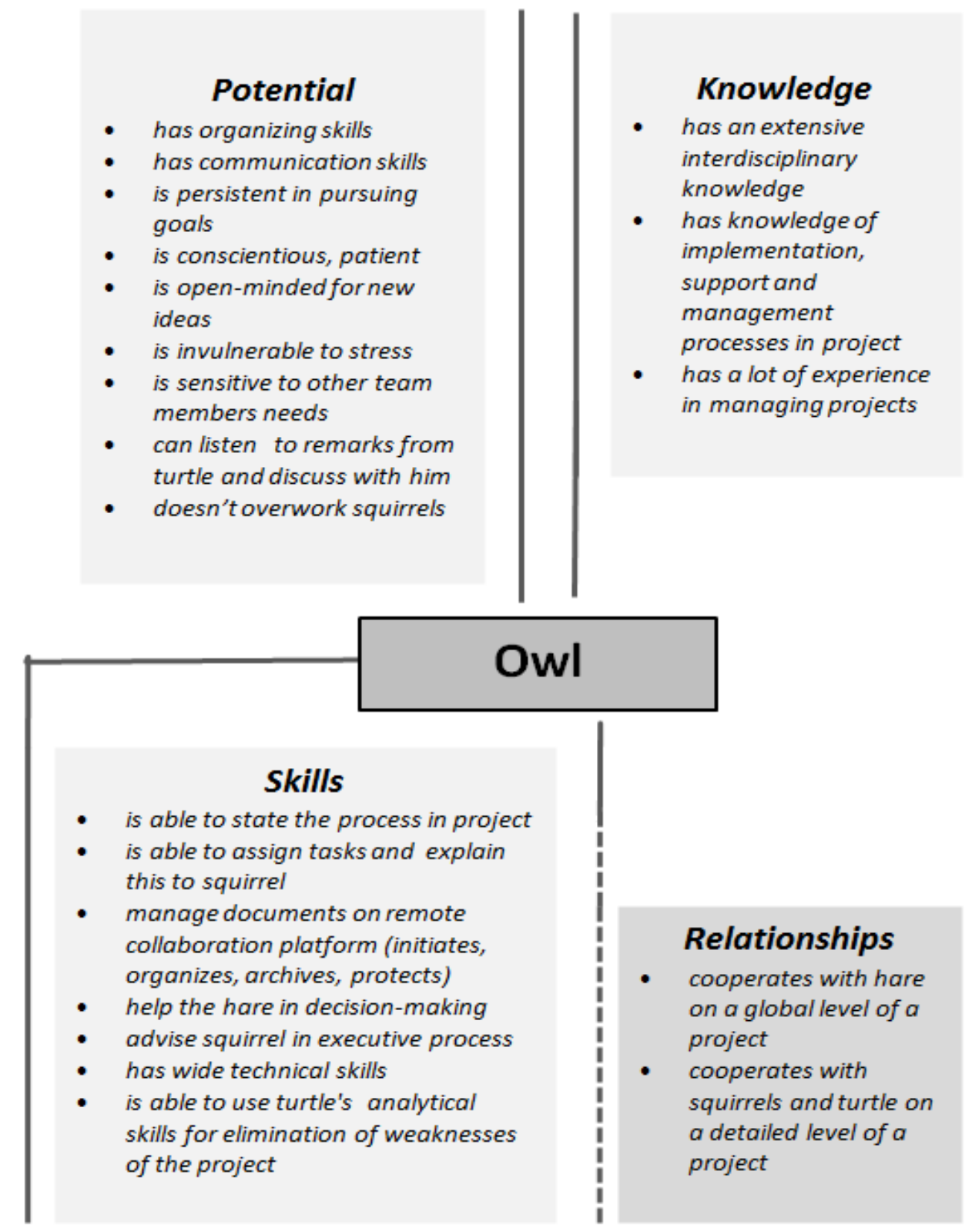

Figure 3. Competence of the owl (source: own elaboration) 
Moreover, it should be persistent in aspiring to purpose, conscientious, and patient. It is a person being in contact with all team members. From the hare receives tasks, which later divides into subtasks and between squirrels. It must have very good communications skills to be able to follow hare's ideas and support the squirrels in their tasks. Its obligation is also to be in contact with the turtle, who seeks imperfections in the performed tasks, and to inform the owl about it. The owl should be able to sense the needs of team members, and in particular, not to push forces of squirrels and not to underestimate the analytical and critical comments of the turtle.

This person must also be aware that although its role is very important, their immediate superior is the hare. An owl has a wide interdisciplinary knowledge similar to the hare, but doesn't have its intuition. However, the owl unlike the hare must know a lot about the detailed objectives carried out by the squirrel; all the more, as they are often subjected to criticism both by themselves and by the turtle. This knowledge must also constantly develop in order to be able to advise the squirrels and make the hare aware that certain matters cannot be resolved as expected.

Then it should also suggest an alternative solution. With regard to the competence focused on remote working, by which the owl should be characterized, above all it includes file management on the platform intended for remote cooperation. This person initiates the creation, archiving, organizing and conducting backup copies. Competences of the owl are presented in Fig. 3.

Squirrel is a person responsible for carrying out detailed tasks of the project, which are often implementation processes. It has a detailed knowledge in a specific discipline. The quality of implementation of the specific task depends on its knowledge.

It reports directly to the owl, which informs it about the assumptions of these tasks and assesses the effects of its work. The squirrel should be a diligent and precise person, disciplined and creative. This person should also be modest in accepting criticism from the owl.

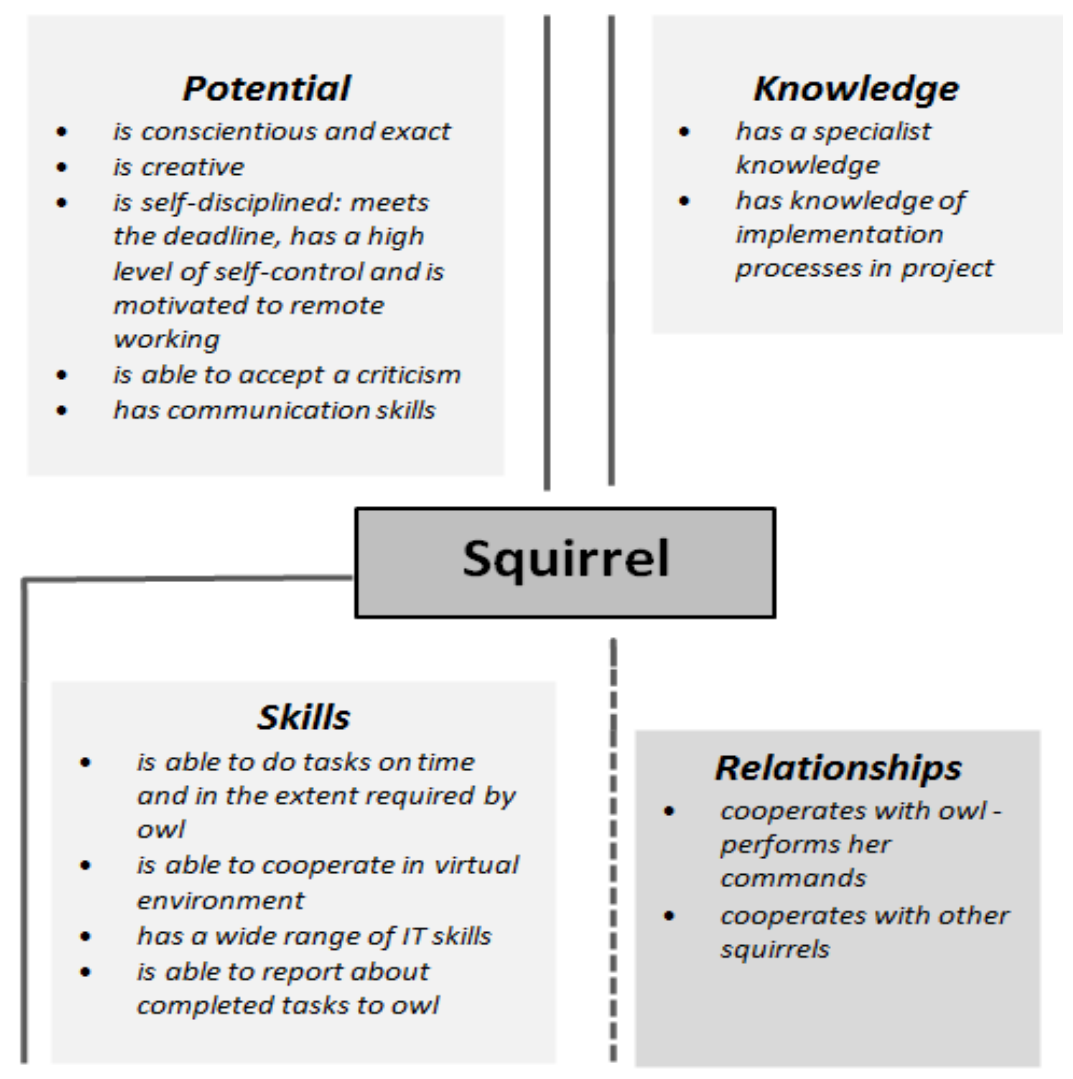

Figure 4. Competence of the squirrel

(source: own elaboration) 
It must have wide digital skills, to be able to work in a remote environment of cooperation, and to be communicative in order to report the owl of the performed works. In addition, remote environment requires high internal motivation to work and selfcontrol from squirrels. Competences of the squirrel are presented in Fig. 4.

Turtle is usually the most thankless role in the project team. It is predicted for person with very good analytical abilities. In addition, it should be able to look at solved tasks in a wide perspective, in order to find potential weaknesses. However, in its criticism, it should above all be constructive and kind.
The turtle's constructiveness should manifest mainly in showing alternative solutions in cases when there is a suggested rejection of proposed solution by the squirrel or owl. The turtle should be able to work in a virtual environment. Similarly, an owl should have both interdisciplinary and detailed knowledge. Only in this way, will it be able to find mistakes and suggest their solutions. The turtle should work with the owl, above all. The owl should not arrange contacts between itself and squirrel, because they can become a source of conflict in the team. Competences of the turtle were presented in Fig. 5.

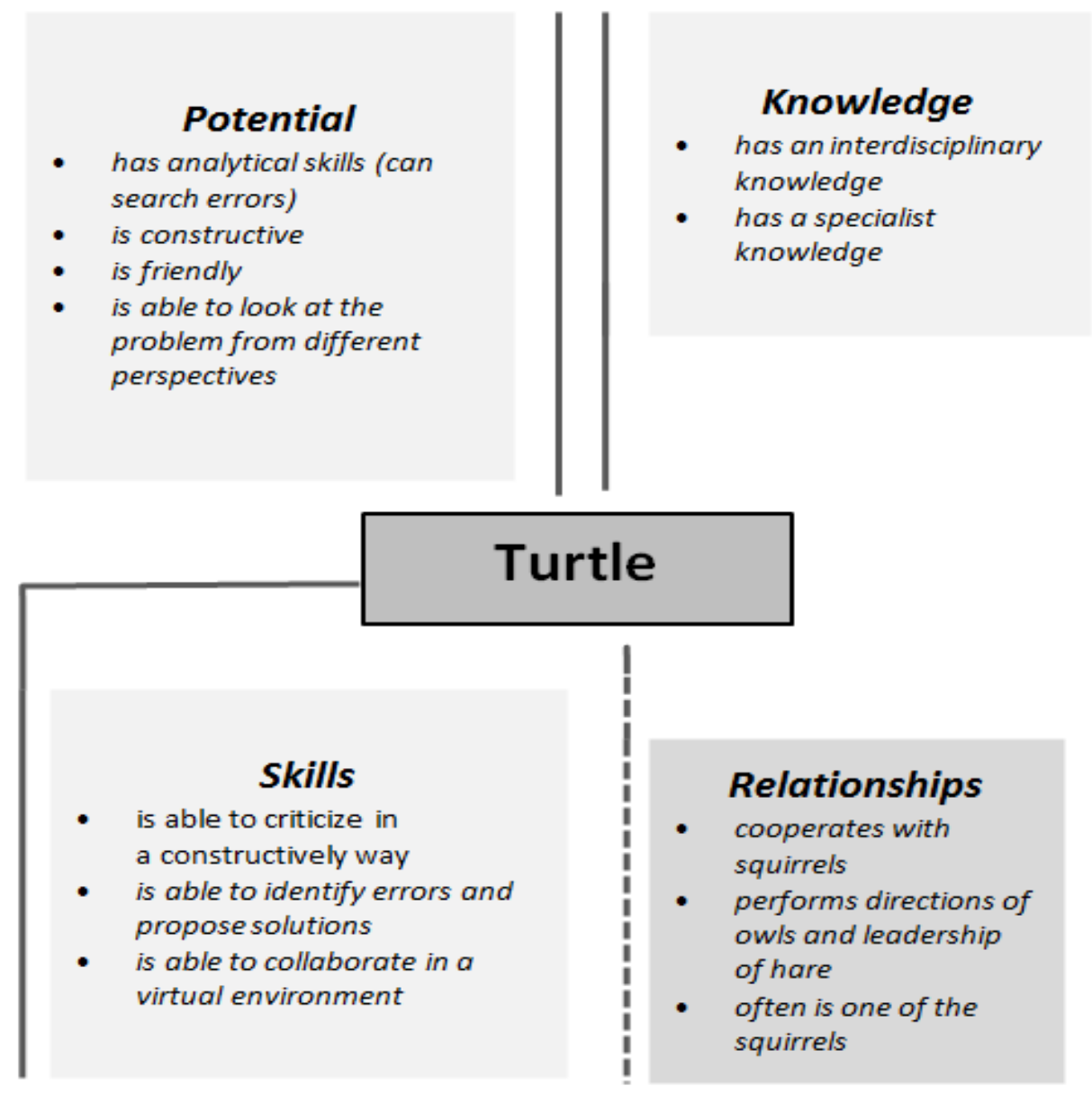

Figure 5. Competence of the turtle (source: own elaboration)

\section{$5 \quad$ Discussion and conclusions}

Project team members in conditions of remote cooperation take the same roles of HOTS model, as the team working in the traditional way. Interview results revealed that each role has its own distinctive competence - very similar to those described in HOTS model in the literature. Therefore, the hare also in remote conditions is a visionary and initiator of the project, the owl is its chief organizer, the squirrel performs specific tasks, and the turtle is an important critic. 
Thus, the basic characteristics of the hare, also in remote conditions, is its creativity, leadership and intuitiveness. In turn, the cardinal feature of the owl is its great organization skills; the squirrel is perfect implementer of the entrusted tasks, and the turtle's strength is analytical skills. The results are that to some extent, the competence of project team members working remotely must agree with the competence of team members working in the traditional way. However, it is worth noticing that they must be supplemented with additional skills, resulting from the specificity of remote working.

The virtual environment requires from the team members to have additional so-called soft competence. Peculiarly, this applies to squirrels, which in the virtual environment must be characterized by greater motivation to work and diligence. In turn, the owl should have wider abilities to inspire a squirrel.

In terms of the so-called technical competence, related to the specificity of remote working, the interviews revealed that in this respect, the greatest competence is expected from the squirrels, who are responsible for the task of implementation processes. High competence in the remote working is also expected from the owl, which consults the implementation of tasks of individual squirrels. What's more, it manages the effects of this work on the platform that supports the work group.

Squirrel, along with the owl, are working on the same files available on the platform, and therefore, appropriate competence of each of the parties to work in the virtual environment determines the effectiveness of the team. Participatory observation revealed that on this background, this may lead to some conflicts and problems with overwriting files.

The owl must cope with such issues, which should not only initiate the creation of next files on a common platform, but also to archive and secure them against accidental deletion or overwriting. In turn, the hare and turtle aren't directly involved in the tasks of implementation processes.

Their skills need not be as specialized as in the case of owls and squirrels. Files are usually available to them in read mode or suggestions. In such cases, the communication via e-mail, phone or social net- works also gains a huge role of consultation in the performed works.

\section{$6 \quad$ References}

[1] A Guide to the Project Management Body of Knowledge, 2013, 5. Edition, PMI, Pennsylvania, p.264.

[2] Belbin, M., 2009. Zespoty zarzadzajqce (Management Teams). Kraków: Wolters Kluwer Business, p.86.

[3] Bratnicki, M., 2000. Kompetencje przedsiębiorstwa. Od określenia kompetencji do zbudowania strategii (Competence of the Company. From the Definition of Competence to Build Strategy). Warszawa: Placet.

[4] Briggs-Myers, I., 1992. Gifts Differing. PaloAlto: Consulting Psychologists Press.

[5] Carter, J.C., Succession Planning By Julien C. Carter Associate Vice President for Human Resources University of Texas at Austin. [online] Available at: https://www.utexas.edu/services/ tacup2009/Succession_Planning_Julien_Carter.p df [Accessed 11 November 2016].

[6] Chełpa, S., 2010. Kierowanie ludźmi $i$ przywództwo (Managing People and Leadership). In: Listwan, T., ed. Zarzqdzanie kadrami (Human Resources Management). Warszawa: Wydawnictwo C.H. Beck.

[7] Crawford, L.H., 2007. Developing Project Management Competence of Individual. In: Turner R.J., Simister S.J., ed. Gower Handbook of Project Management. Edition 4, Gower, Aldershot, pp.707-724, 678-694.

[8] Czakon, W. Mity o badaniach jakościowych w naukach o zarzadzaniu (Myths About Qualitative Research in Management Sciences). [online] Available at: http://www.wojciechcz akon.com/pub/mity-o-badaniach-jakosciowychw-naukach-o-zarzadzaniu.pdf [Accessed 16 November 2016].

[9] Hamersly, B., Land, D., 2015. Building Productivity in Virtual Project Teams. Revista de Gestão e Projetos, Vol. 6 (1), pp.1-13.

[10] Hansen, M.V, Allen, R.G., 2010. Jednominutowa gotówka (One-minute Cash). MT Biznes. 
[11] Hansen, M.V, Allen, R.G., 2002. The One Minute Millionaire: The Enlightened Way to Wealth, Harmony Books.

[12] Hofrichter, D.A., Spencer, L.M.,1996. Competencies: The Right Foundation for Effective Human Resource Management, Compensation and Benefits Review, 28(6), pp.21-24.

[13] Hysa, B., Rakowska, A., 2014. Umiejętności decyzyjne jako kluczowe kompetencje $w$ pracy kierownika administracji samorzadowej (Decision-making Skills as Key Competencies in the Work of the Head of Local Administration). Zeszyty Naukowe Politechniki Śląskiej, Organizacja i Zarządzanie, z. 68, pp.14-15.

[14] Jokinen T., 2005. Global leadership competencies: a review and discussion. Journal of European Industrial Training, Vol. 29 (3), pp.199216.

[15] Katz, R. L., 1995. Skills of an effective administrator. Harvard Business Review, Jan-Feb, pp.33-42.

[16] Kiełtyka, K., 2016. Zarządzanie zespołami projektowymi. Kto jest kto w projekcie? (Management of Project Teams. Who is Who in the Project?). In: Sołtysik, M., Wesołowska, M., eds. Wspótczesne trendy $w$ zarzqdzaniu projektami (Contemporary Trends in Project Management). Kraków: Mfiles.pl, pp.135-142.

[17] Listwan, T., ed., 2010. Zarzqdzanie kadrami (Human Resources Management). Warszawa: C.H. Beck.

[18] Morley, S., Cormican, K., Folan, P., 2015. An Analysis of Virtual Team Characteristics A Model for Virtual Project Managers. Journal of Technology Management \& Innovation, Vol. 10(1), pp.188-203.

[19] Musioł-Urbańczyk, A., 2010. Kompetencje kierownika projektu i możliwości ich ksztaltowania (Competence of the Project Manager and Their Ability to Shape). Gliwice: Wydawnictwo Politechniki Śląskiej, pp.26-27.

[20] Polskie Wytyczne Kompetencji IMPA, wersja 3.0. (Polish IPMA Competence Guidelines, version 3.0), 2009. SPMP, Gdańsk, pp.92-94.

[21] Piccoli, G., Powell, A., Ives, B., 2004. Virtual Teams: Team Control Structure, Work Process- es, and Team Effectiveness. Information Technology \& People, Vol.17 (4), pp.359-379.

[22] Rakowska, A., 2007. Kompetencje menadżerskie kadry kierowniczej we wspótczesnych organizacjach (Management Competencies of Management in Modern Organizations). UMCS, Lublin, p.144.

[23] Rakowska, A., Sitko-Lutek, A., 2000. Doskonalenie kompetencji menedżerskich (Management Competencies of Management in Modern Organizations). Warszawa: PWN, pp.9-17.

[24] Rashid, G.J.,' Duy, D.K., 2015. Counselor Cognitive Complexity: Correlating and Comparing the Myers-Briggs Type Indicator With the Role Category Questionnaire. Journal of Employment Counseling, Vol. 52(2), pp.77-78.

[25] Stankiewicz, K., Birr, K., 2014. Doskonalenie procesu zarządzania zespołem w oparciu o zróżnicowanie typów MBTI (Improve Team Management Process Based on Differentiation of MBTI Types). Przedsiębiorstwo we współczesnej gospodarce - teoria i praktyka (Company in the Modern Economy - Theory and Practice), No. 4, pp.34-35.

[26] Thierry, D., Sauret, C., 1994. Zatrudnienie $i$ kompetencje $w$ przedsiębiorstwie $w$ procesie zmian (Employment and Competence in the Enterprise in the Change Process). Warszawa: Poltex.

[27] Turner, R.J., Müller, R., 2010. Advances in Project Management: Project-Oriented Leadership. Gower, Farnham, pp.8-9.

[28] Twardochleb M., 2014. Dobór zespołów projektowych z wykorzystaniem metod statystycznych (Selection of Design Teams Using Statistical Methods). Informatyka Ekonomiczna (Business Informatics), 1(31), pp.223-236.

[29] Verschuren, P.M., 2003. Case Studies as a Research Strategy: Some Ambiguities and Opportunties. International Journal of Social Research Methodology, Vol. 6, No. 2, pp.121-139.

[30] Wachowiak, P., Gregorczy, S., Grucza, B., Ogonek, K., 2004. Kierowanie zespotem projektowym (Managing the Project Team). Warszawa: Difin, pp.27. 
[31] Wasiluk, A., 2008. Kompetencje przywódcze w przedsiębiorstwach o zasięgu globalnym (Leadership Competencies in Global Companies). In: Budzisz, B., Urban, W., Wasiluk, A., eds. Stymulowanie rozwoju przedsiębiorstwa (Stimulate the Development of the Enterprise), Warszawa: Difin, pp.67-68.

[32] Witkowski, A.S., Ilski, S., 2000. Walidacja Kwestionariusza Ról Zespołowych: A SelfPerception Inwentory R.M. Belbina. Przeglad Psychologiczny (Psychological Review), Vol. 43, No. 1, pp.47-49.
[33] Wróblewski, P., 2005. Zarzadzanie projektami informatycznymi dla praktyków (Management of IT Projects for Practitioners). Gliwice: Helion.

[34] Zdonek, I., Wolny, M., 2015. Potencjał pracownika - koncepcja modelu badawczego (Employee Potential - Concept of Research Model). Zeszyty Naukowe Politechniki Ślaskiej, Organizacja i Zarzadzanie, Vol. 86, pp.205-2015. 